\title{
がん薬物療法の個別化·適正化に関する研究
}

\author{
寺田智祐
}

\section{Pharmaceutical Investigation for Individualized and Optimal Cancer Pharmacotherapy}

\author{
Tomohiro Terada \\ Department of Pharmacy, Shiga University of Medical Science Hospital; \\ Tsukinowa-cho, Seta, Otsu 520-2192, Japan.
}

(Received June 19, 2016)

\begin{abstract}
After the year 2000, the treatment of cancer remarkably changed, including the development of outpatient cancer chemotherapy. Meanwhile, we have encountered many clinical problems related to cancer patient pharmacy services. To resolve these problems, I have tried to establish the individualized and optimal cancer pharmacotherapy utilizing the findings of basic research. In this review, three topics of my research will be introduced. 1) In 2005, information regarding the genetic polymorphism of $U G T 1 A 1^{*} 28$ was described in the package insert of the drug irinotecan in the United States. At that time, however, there was little similar information for Japanese patients. Through clinical research, we demonstrated that $U G T 1 A 1^{*} 6$ was a significant factor for neutropenia, as induced by irinotecan. 2) Tyrosine kinase inhibitors are mainly used at a fixed dose, but wide interpatient variability has been observed relative to their pharmacokinetics and/or pharmacodynamics. To overcome these variations, clinical and basic pharmacological research on erlotinib, sorafenib and sunitinib was carried out. Especially, in sunitinib therapy, we demonstrated that the breast cancer resistant protein in the intestine functions as a limiting factor for oral absorption, and that therapeutic drug monitoring could be helpful for avoiding severe toxicities, resulting in prolonged progression-free survival. 3) We quantitatively assessed side effect management by pharmacist intervention for outpatient chemotherapy. We calculated the improvement ratio between before and after pharmacist intervention, and found that 135 suggestions (50.8\%) led to significant improvements, indicating that pharmacist intervention could be useful for attenuating the side effects of cancer chemotherapies.
\end{abstract}

Key words_— clinical pharmacology; drug transporter; genetic polymorphism; outpatient chemotherapy; pharmacist intervention

\section{1. 緒言}

2000 年に入り, がん治療を取り巻く環境は一変

した．外来化学療法の普及に始まり，がん専門薬剂 師制度やがんプロフェッショナル養成プランのス タート, がん対策基本法の施行など, 様々な施策実 施と基盤整備が進むとともに，毎年多種多様な新規 抗がん薬が上市されてきた。 そんな中, 筆者は, 入 院・外来での抗がん薬の無菌調製や消化器外科病棟 での薬剤管理指導などがん薬物療法関連業務に携わ る中で，副作用に苦しむ患者さんや処方設計に悩む 臨床医を目の当たりにし, 多くの臨床的課題に直面

滋賀医科大学医学部附属病院薬剂部（T520-2192 滋賀 県大津市瀬田月輪町)

e-mail: teradat@belle.shiga-med.ac.jp 本総説は, 第 39 回佐藤記念国内賞の受賞を記念して記 述したものである.
してきた。 それらの課題を解決するため，基礎研究 の活動で培ったノウハウを活用して，がん薬物療法 の適正化・個別化の確立に努めてきた，以下に，主 な研究成果を紹介する.

\section{2. 抗がん薬による有害事象発現の要因探索}

一般に, 抗がん薬の第 I 相試験では, 最大耐用 量, すなわち毒性を指標に推奨用量が設定され, 続 く第 II - III 相試験でその効果が検証されていく．し かし, 日常臨床では治験のエントリー基準に合致し ない患者の多くにも，抗がん薬が投与されることに なり，新規抗がん薬を中心にその有害事象発現の要 因探索を行うことは, 安全ながん薬物療法を実施す る上で極めて重要である。これまで筆者は，新たに 上市された抗がん薬を中心に, 有害事象発現に関連 した臨床因子を同定してきた. ${ }^{1-11)}$ 本稿では，イリ ノテカンの好中球減少に及ぼす, 遺伝子多型の影響 
について解析した結果を紹介する.

トポイソメラーゼ阻害薬であるイリノテカンは, カルボキシルエステラーゼによって活性代謝物 SN-38 に変換される。 SN-38 は，主に肝臓でグルク ロン酸転移酵素（uridine diphosphate-glucuronosyltransferase 1A1；UGT1A1）によるグルクロン酸 抱合反応を受けて不活化されることから, 薬物相互 作用や遺伝子多型による UGT1A1 の活性低下は, 解毒代謝の遅延による血中 SN-38 濃度の上昇を招 き，副作用発現の原因になり得ると考えられた。 2000 年頃より，イリノテカンに関する臨床薬理学 的研究の成果が国内外から報告され, 12,13) 2005 年, $U G T 1 A 1^{*} 28$ の木モ接合では, 好中球減少のリスク が高くなるため，初回投与量は少なくとも 1 レベル 減量するように, 米国での添付文書が改訂された。

日本人を含むアジア人では，UGTIAI*28 の頻度 が低かったことから，日本人におけるイリノテカン の毒性発現に及ぼす $U G T 1 A 1$ 遺伝子多型の臨床的 意義について検討を加えた。まず，UGTIA1*6, $U G T 1 A 1^{*} 27, U G T 1 A 1^{*} 28, U G T 1 A 1^{*} 60$ の簡便な遺 伝子多型解析法を確立した. ${ }^{14)}$ 次に, イリノテカン を投与された 133 名の 1 コース期間中の Grade 3-4 の好中球減少に及ぼす, 患者背景や 4 種の $U G T 1 A 1$ 遺伝子多型の影響を調べた。各 UGTIAI 遺伝子多型のアレル頻度は既報と類似しており, $U G T 1 A 1^{*} 6$ をホモで有する患者は 6 名であったの に対して，UGTIA1*28 をホモで有する患者は 1 名 であった. Grade 3-4 の好中球減少は，29名(22\%) の患者に認められた。患者背景と好中球減少の関連 について単変量解析を行つたところ, イリノテカン 投与前の好中球数值と総ビリルビン值が有意な因子 として同定された。次に，好中球減少とUGTIAI 遺伝子多型について単変量解析したところ, $U G T 1 A 1^{*} 6$ の夕有意な関連を示した。ささらにこ れらの因子を含めたロジスティック回帰分析を行っ た結果，UGTIAI*6が単独の因子として同定され， $U G T 1 A 1^{*} 6$ を木モで有する患者の好中球減少症の オッズ比は 7.63 （95\% 信頼区間， $1.05-55.61 ; p<$ 0.05）と算出された.

以上の結果より，イリノテカンによる好中球減少 とUGT1A1*6は，強く関連していることを明らか にした. ${ }^{1)}$ 一方，同時期に韓国 ${ }^{15)}$ や日本 ${ }^{16)}$ からも同 様の報告がなされ，アジア人においては，

Table 1. Problems of Oral Molecular Targeted Drugs

\begin{tabular}{ll}
\hline \hline Drug & Expense \\
& Severe side effects including interstitial pneumonia \\
& Large interpatient variability in PK \\
& Poor data from Japanese patients resulting from \\
& dissolving medical drug lag \\
Patient & Problem of adherence \\
& Discontinuation of administration due to severe \\
& side effects \\
& Poor data on special populations \\
\hline
\end{tabular}

UGTIAI*6/ $/{ }^{*} 6, U G T 1 A I^{*} 28 /{ }^{*} 28, U G T 1 A I^{*} 6 /{ }^{*} 28$ がハイリスク遺伝子多型として認識されるように なった。なお，日本では，2008 年にイリノテカン の UGT1A1 遺伝子多型情報が添付文書に記載さ れ，その検査についても保険収載が行われた。

\section{3. 経口分子標的抗がん薬の体内動態·薬効の個} 体差解明

慢性骨髄性白血病治療薬イマチニブの開発を契機 として, 数多くの経口分子標的抗がん薬が臨床に導 入されてきた。一方，経口分子標的抗がん薬は，

Table 1 に示すような問題点があり，適切な支持療 法や，患者視点に基づいた服薬指導など，きめ細や かな薬物療法の実践が求められていた.

このような問題点克服の方法として, pharmacokinetics (PK) と pharmacodynamics (PD) 解析に 基づいた，薬物血中濃度モニタリング（therapeutic drug monitoring；TDM）が挙げられる. TDM は, 薬物療法の有効性/安全性を担保する有用なツール であるが，これまで注射がメインであった抗がん薬 では，採血のタイミングが煩雑なこともあり，抗が ん薬の TDM はほとんど臨床応用されてこなかっ た. ${ }^{17)} し か し ，$ 経口分子標的抗がん薬の場合，長期 間連続して内服するため, トラフ濃度から薬物の曝 露量を推測することが可能となり, ${ }^{17)}$ その臨床的有 用性が，慢性骨髄性白血病治療薬のイマチニブで

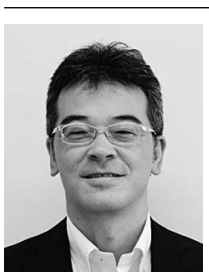

寺田智祐
1994 年京都大学薬学部卒業, 1999 年同 大学院薬学研究科博士課程修了. 日本 学術振興会, 京大病院薬剂部などを経 て，2010 年より滋賀医大病院薬剂部 教授・薬剂部長 (現職)。2 007 年日本 薬学会奨励賞受賞. 現在, 日本薬学会 の医療薬科学部会世話人・広報委員・ BPB 及び薬学雑誌編集委員を務めてい る. 


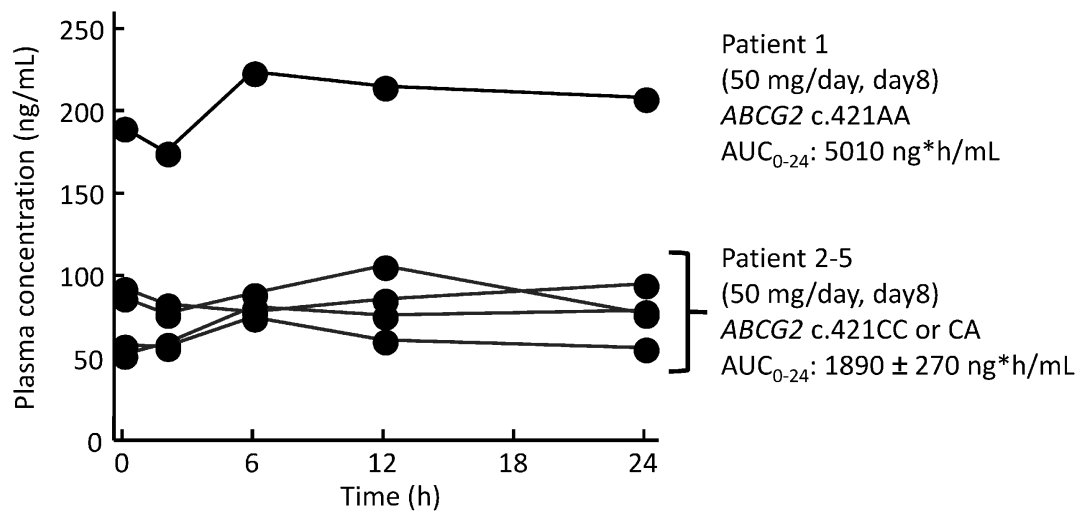

Fig. 1. Relationship between Plasma Concentration-Time Profile of Sunitinib and Genetic Polymorphisms of $A B C G 2$

2007 年頃から明らかになりつつあつた. ${ }^{18,19)}$ このよ うな背景の下，筆者らは，2000 年代後半に上市さ れたソラフェニブ, ${ }^{20,21)}$ スニチニブ, ${ }^{22-26)}$ エルロチ ニブ27-29)を対象として, 血中濃度解析に基づいた体 内動態・薬効の個体差の要因を究明し, 総説として 発表した. ${ }^{30)}$ 本稿では, 腎細胞がん治療薬であるス ニチニブの個別化薬物療法の確立と, 透析患者にお ける経口分子標的抗がん薬の PK/PD 解析について 紹介する.

3-1. スニチニブの個別化薬物療法の確立 ス ニチニブは，マルチキナーゼ阻害薬として 2008 年 にわが国に導入された経口分子標的抗がん薬であ る.しかし, 厚生労働省の未承認使用問題検討会議 で早期承認が必要と判断された経緯もあり, 海外で の用法・用量がそのまま国内に導入されている，好 中球減少症や血小板減少症などの副作用が欧米人よ りも日本人で高頻度に発現するため, 標準投与量で の治療継続が困難となる症例が多い。さらに，ス二 チニブでは投与を中止すると一気に病勢が進行する リバウンド現象も認められ, 患者個別の投与量設定 や副作用モニタリングが, 精度高く求められる経口 分子標的抗がん薬である.

スニチニブが臨床使用された当初, 服薬治療開始 早期に Grade 3-4 の様々な有害事象を呈した症例を 経験した. 当該患者 $(n=1)$ の服用後 8 日目の血 中濃度を測定し, 他の患者 $(n=4)$ の血中濃度プ ロファイルと比較したところ，スニチニブの最高血 中濃度や薬物血中濃度-時間曲線下面積 (area under the curve; AUC) は約 2.5 倍大きかった（Fig. 1). 当該患者において血中濃度が上昇した原因を探 索したが, 薬物相互作用, 肝腎機能低下, 過量投与
などは認められなかった。 そこでスニチニブの体内 動態に関連していると考えられた因子の遺伝子多型 解析を実施したところ, 重篤な副作用を呈した患者 では, 薬物排出トランスポーター brest cancer resistant protein (BCRP/ABCG2) の遺伝子多型に おいて, $A B C G 2$ c.421C $>\mathrm{A}$ （p.Q141K）のホモ型 を有していた。一方, 他の患者は野生型 $(n=3)$ 並びにへテロ型 $(n=1)$ であった. ${ }^{22)}$

ABCG2 は ABCトランスポーターの一種で, 消 化管上皮細胞の管腔側に発現し, 種々薬物の細胞内 から管腔側への輸送を媒介することによって, 消化 管吸収過程を制御している。 p.Q141K の変異を有 すると細胞膜における発現量が減少し, 結果的に輸 送能が低下することが知られている. ${ }^{31)}$ そこで, $A B C G 2$ c. $421 \mathrm{C}>\mathrm{A}$ の変異を有する患者では, 消化 管における ABCG2 発現量が低下し，スニチニブの 消化管吸収が増大し全身曝露量が増えて, 重篤な有 害事象を発症したという仮説を立てた。この仮説の 検証に取組むため, in vitro 輸送実験, in vivo 動物 実験，そしてヒトを対象にした臨床薬物動態解析を 実施した。

まず， スニチニブが ABCG2 の基質になるか否か について, in vitro 輸送実験を行つた。 その結果, スニチニブは $\mathrm{ABCG} 2$ の基質になることが判明し た. ${ }^{22)}$ 次に, $A b c g 2$ 遺伝子欠損動物を用いて, ス二 チニブの体内動態特性について調べた。遺伝子欠損 動物では野生型に比べて経口投与時の AUC が有意 に上昇したが，静脈内投与では両者の AUC に差は 認められなかった. ${ }^{23)}$ またスニチニブ服用患者数を 増加させ, AUC に及ぼす $A B C G 2$ c. $421 C>\mathrm{A}$ の影 響を調べたところ, ホモ型>ヘテロ型>野生型の順 
でスニチニブの AUC は増加した。 したがって，当 初の仮説通り, $A B C G 2 \mathrm{c} .421 \mathrm{C}>\mathrm{A}$ の遺伝子多型 は，スニチニブの曝露量増加と密接に関連している ことが示された。興味深いことに，ABCG2 c.421C $>\mathrm{A}$ の遺伝子多型の頻度は, 欧米人よりも日本人 の方が多いことが報告されており， ${ }^{32)}$ スニチニブに よる副作用発現の人種差に, この多型が一部関与し ている可能性が示唆された。ささに，母集団薬物動 態解析の手法を用いて，ABCG2 c.421C >A の遺伝 子多型変異に応じたスニチニブの血中濃度シミュ レーションに成功し, 日常診療への応用可能性を提 示することができた. ${ }^{25)}$

スニチニブによる薬物療法前に, $A B C G 2$ c. $421 \mathrm{C}$ $>\mathrm{A}$ の遺伝子多型の有無を把握しておくことは, あらかじめリスクを把握しておくという観点から有 用であるが，きめ細やかな投与量の調節には TDM が不可欠であると考えた。これまで，動物実験では 血中の総スニチニブ濃度（スニチニブと活性代謝物 SU12662 の総和）が 50-100 ng/mL において，移植 されたがん組織における標的分子のリン酸化が阻害 されることが報告されている. ${ }^{33)}$ また海外の第 I 相 試験では，総スニチニブ濃度が $100 \mathrm{ng} / \mathrm{mL}$ を超え た症例で，用量制限毒性が多く認められたとも報告 されている. ${ }^{34)}$ そこで，スニチニブの至適濃度を探 索するため, 血中の総スニチニブ濃度と副作用発現 の頻度・重篤度, 曝露量と腫瘍縮小効果や治療成功 期間（time to treatment failure; TTF)，及び無増悪 生存期間（progression-free survival; PFS）の関連 性についてレトロスペクティブに解析した.

スニチニブは，4 週間投与 2 週間休薬で投与され， 1 サイクル目の定常状態におけるトラフ值を指標と した。このトラフ值が $100 \mathrm{ng} / \mathrm{mL}$ 以上の群を高曝 露群, $100 \mathrm{ng} / \mathrm{mL}$ 未満の群を低曝露群として，2 群 間で比較した。総スニチニブ濃度の中央值は 91.8

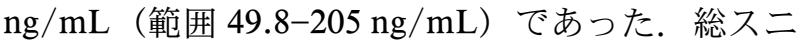
チニブ濃度と血小板数は, 有意な負の相関を示し た。また総スニチニブ濃度は，食欲不振，倦㤐感の 重篤度と有意な相関を示した。低曝露群（範囲： 49.8-93.5 ng/mL, $n=13 ）$ の患者は，高曝露群の患 者（範囲：106-205 ng/mL, $n=8 ）$ と比較して, Grade 3 以上の毒性を発現した頻度は低かった（23 \% vs. 75\%)。低曝露群の患者における最大腫瘍縮 小効果は, partial response (PR) が 3 名 (23.1\%), stable disease (SD) が 8 名 $(61.5 \%)$ であった。 一方，高曝露群の患者では SD が 7 名（87.5\%）で あった。また低曝露群の患者では TTF 及び PFS は，高曝露群の患者と比較して有意に長かった (TTF 中央値 590 日 $v s .71$ 日 $p<0.05, \mathrm{PFS}$ 中央值 748 日 $v s .238$ 日 $p<0.05)$. したがって, 総スニチ ニブ濃度が高值であると副作用発現のリスクが高ま り，特に $100 \mathrm{ng} / \mathrm{mL}$ を超えた場合，スニチニブの 服用継続が困難となり，PFS が短縮する傾向が認 められた. ${ }^{26)}$

これらの結果より，スニチニブの個別化薬物療法 の戦略として，遺伝子多型と TDM を組み合せるこ とを提唱した（Fig. 2)。すなわち，投与前に $A B C G 2$ c. $421 \mathrm{C}>\mathrm{A}$ の遺伝子多型を解析することに よって, 有害事象の発生リスクをあらかじめ把握す ることができる．日々の薬物療法では，定期的に血 中濃度を測定し, トラフ值が $100 \mathrm{ng} / \mathrm{mL}$ を超過し ないように投与量を調整する。このように，スニチ ニブの薬物療法をきめ細やかに設計することによっ て，副作用を回避して生存期間の延長につながる可 能性が示唆された。

\section{3-2. 透析患者における分子標的抗がん薬のPK/} PD 解析一般に, 日本人のスペシャルポピュ レーションにおける，抗がん薬の投与設計について はエビデンスがそしい。特に, 慢性腎臟病患者の増 加に伴い，透析患者のがんの罹患率も上昇し，これ らの患者に分子標的抗がん薬を投与する機会も増え てきている，そこで，透析施行患者において，分子 標的抗がん薬の PK/PD 解析を行つた事例について 紹介する.

3-2-1. ソラフェニブ20) 54 才男性. 腎細胞が ん.ソラフェニブは $200 \mathrm{mg} /$ 日から開始し， $800 \mathrm{mg}$ /日まで漸増した。Day 183 にソラフェニブと活性 代謝物 M-2 の血中濃度解析を実施したところ，既 報の非透析患者の薬物動態学的パラメータと一致し ていた。ソラフェニブは約 6 カ月間継続され, 減量 /中止を要する重篤な副作用はなかった.

3-2-2. スニチニブ24) 66 才男性. 腎細胞が ん. スニチニブは $25 \mathrm{mg} /$ 日を 4 週間投与 2 週間休 薬で開始した。透析日及び非透析日に総スニチニブ 濃度を測定し，それぞれの $\mathrm{AUC}_{0-24}$ 值は透析日と 非透析日に差はなかった。また定常状態における総 スニチニブ濃度は，有効域と想定される 50-100 ng 


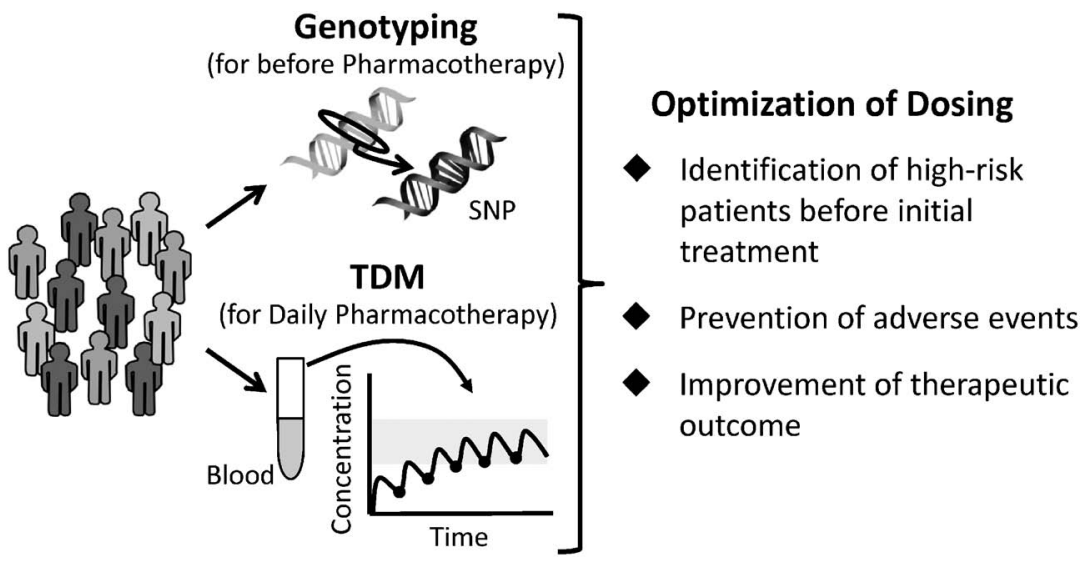

Fig. 2. Strategy for Optimal Pharmacotherapy of Sunitinib

$\square$ Grade $0 \quad \mathbb{\$}$ Grade 2

$\square$ Grade $1 \square$ Grade 3

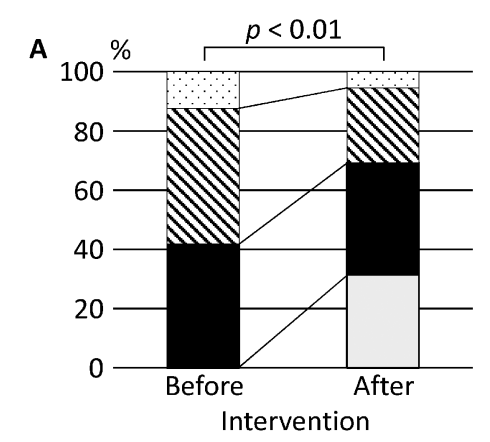

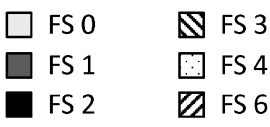

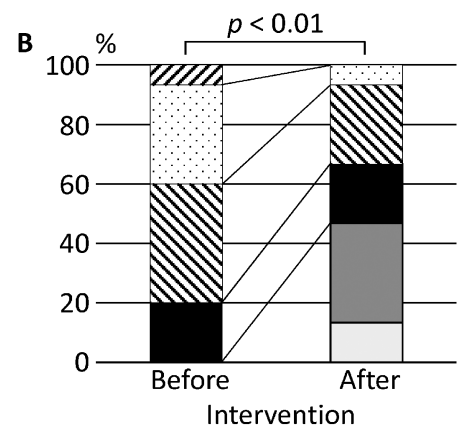

Fig. 3. Effect of Pharmacists' Intervention on the Grade of Side Effects (A) and Face Scale (B)

$/ \mathrm{mL}$ の範囲内であった。重篤な副作用もなく, 2 クール目終了後画像評価によって, 肺転移巣は PR であった。

3-2-3. パゾパニブ35)

70 才男性。腎細胞が

ん. パゾパニブが $400 \mathrm{mg} /$ 日で開始された。 パゾパ ニブ開始 3 日後に Grade 3 の肝機能障害が発現し た。休薬 10 日後に，パゾパニブ $200 \mathrm{mg}$ を隔日で 再開され，再開 7 日後のトラフ濃度（透析前）は $2.9 \mu \mathrm{g} / \mathrm{mL}$ と低值であり（推定有効トラフ值：> $\left.20.5 \mu \mathrm{g} / \mathrm{mL}^{36)}\right)$, 副作用を認めなかつたため $200 \mathrm{mg}$ を連日投与とした。パゾパニブ開始 34 日目（非透 析日）及び 35 日目（透析日）にパゾパニブの血中 濃度解析を実施したところ, 各群のトラフ值（ $\mu \mathrm{g} /$ mL）は，13.4 及び 15.4 であった。 また，その他の 両群の薬物動態学的パラメータも両群で類似してい た. 投与開始 60 日目に, Grade 1 の肝機能障害を 発現したためパゾパニブは中止となった.
一般に，透析患者における薬物の排泄を考える場 合には，薬物自体の腎排泄性とともに，透析による 薬物除去の程度，すなわち透析性を評価することが 重要である。透析性に影響を及ぼす薬物動態学的パ ラメータとしては, タンパク結合率と分布容積が挙 げられる，すなわち，タンパク結合率の大きい薬物 では，分子サイズの関係から透析膜を通過すること が困難となり，透析性は悪くなる。一方で分布容積 の大きい薬物，すなわち血獎以外の組織に多く分布 している薬物は, 血液浄化療法によって直接除去で きないため，こちらも透析性は悪くなる．特に脂溶 性の高い薬物の場合, 組織・筋肉等へ高濃度に分布 するとともに，タンパク結合率も高くなり，血液透 析ではほとんど除去されない. 上記 3 種類を含む多 くの経口分子標的抗がん薬は，これらの特性を有し ていることから, 透析患者へ投与する際には, 減量 を考慮しなくてもよいと考えられる. 
4. がん領域の薬剤業務に関するエビデンス構築

これまで述べてきた臨床薬理学的アプローチに基 づくがん薬物療法の個別化・適正化に加えて，がん 領域の薬剤業務に関連して発生する様々な課題・疑 問点について，科学的基盤の構築に努めてきた。例 えば，外来化学療法における携帯型持続注入器の精 度調査や, 外来における経口抗がん薬の患者教育シ

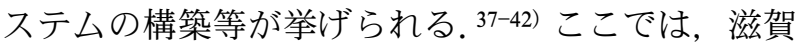
医科大学着任後の, 外来化学療法患者への介入事例 について紹介する.

滋賀医科大学医学部附属病院では, 2010 年か ら，外来がん化学療法を施行される全患者を対象 に，服薬指導や副作用モニタリングに基づいた処方 の提案を行ってきた. 当初, 患者の自覚症状の改善 を指標として，その薬学的ケアの有用性を明らかに

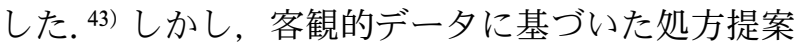
の有用性についてはエビデンスがそしかったことか ら，定量的な評価を実施するために，有害事象に関 しては Grade，疼痛緩和に関しては face scale (FS) 法を用いて，薬剤師による介入の有用性を評価し た. ${ }^{44)} 2011$ 年 10 月から 2012 年 10 月に外来がん化 学療法は 3444 件施行され, そのうち処方提案を 行った事例 331 件を対象に副作用改善率を解析した ところ，317 件（95.8\%）が採用され，266 件が評 価可能であった。その内訳は口腔粘膜炎 37 件, 悪 心 36 件, 皮膚症状 30 件（ざ瘡様皮疹，皮膚乾燥， そう棒症), 神経系障害 29 件, 倦怠感 28 件, 下痢 27 件, 便秘 21 件, 疼痛 15 件, 味覚異常 14 件, 手 足症候群 12 件, 爪囲炎 11 件, 嘔吐 6 件であった. 評価可能 266 件のうち，135 件（50.8\%）に薬剤師 介入後では, 介入前に比べて Grade 及び FS いずれ のスコアも有意な改善が認められた（Fig. 3)。さ らに，自覚症状を含めた評価では，処方提案が採用 された事例の $69.5 \%$ で改善が得られた。疼痛，口 腔粘膜炎, 皮膚症状については改善率が高かつた が, 倦怠感, 神経系障害, 味覚異常の 3 項目は改善 率が低く, 特に神経系障害と味覚異常は改善率が $20 \%$ 以下であった。効果的な支持療法が確立されて いるか否かが，改善率の高低と相関しており，改善 率の低い有害事象については，支持療法の再検討 や，治療効果を考慮しながら原因薬剂の減量及び中 止など支持療法以外の対処法を検討する必要がある と考えられた。
これらの結果より，薬剤師が外来がん化学療法施 行患者に対して，副作用モニタリングと処方提案を 行うことは，患者の副作用軽減と治療満足につなが ることが明らかになった．本報告に限らず，近年， 薬剂師外来など，外来がん化学療法へ薬剂師が関与 することの有用性が多数報告され, ${ }^{45-47)}$ 平成 26 年 度診療報酬改定時にはがん患者指導料 3 が新設され た。今後はこれらの薬剤師による指導や介入が，相 対治療強度の維持や患者の生存期間の延長にどの程 度影響を及ぼすのか，患者ベネフィットに資するよ うなエビデンスを発信し続けることが強く求められ るであろう。

謝辞本受賞研究は，筆者が京都大学医学部附 属病院薬剂部及び滋賀医科大学医学部附属病院薬剤 部在籍中に行った研究であります。両病院の薬剂部 教職員・学生の皆様と, 共同研究者として参画して 頂いた多くの方に，心よりお礼と感謝を申し上げま す．特に，薬剤業務の科学的エビデンス構築に熱い 情熱を持ってご指導頂きました乾 賢一先生（京都 大学名誉教授, 京都薬科大学名誉教授) と, 薬剂 師・薬剤部長としての矜持をご指導頂いた松原和夫 先生（京都大学医学部附属病院 教授・薬剤部長） に深謝申し上げます。最後になりますが，選考及び 承認を賜りました日本薬学会及び佐藤記念基金の関 係各位に謹んで深謝申し上げます。

利益相反＼cjkstart開示すべき利益相反はない.

\section{REFERENCES}

1) Onoue M., Terada T., Kobayashi M., Katsura T., Matsumoto S., Yanagihara K., Nishimura T., Kanai M., Teramukai S., Shimizu A., Fukushima M., Inui K., Int. J. Clin. Oncol., 14, 136-142 (2009).

2) Fujisawa H., Hashida T., Terada T., Katsura T., Ishiguro H., Yoshibayashi H., Inui K., Jpn. J. Pharm. Health Care Sci., 35, 31-36 (2009) .

3) Kitazawa F., Terada T., Takahashi K., Matsumoto S., Inui K., Jpn. J. Pharm. Health Care Sci., 35, 337-342 (2009).

4) Miura A., Onoue M., Terada T., Takahashi K., Inui K., Jpn. J. Pharm. Health Care Sci., 
36, 57-60 (2010).

5) Mitsuyu H., Onoue M., Terada T., Ikemi Y., Takahashi K., Katsura T., Inui K., J. Jpn. Soc. Hosp. Pharm., 46, 1653-1656 (2010).

6) Tsujii S., Onoue M., Terada T., Ikemi Y., Yanagihara K., Katsura T., Inui K., J. Jpn. Soc. Hosp. Pharm., 48, 719-723 (2012).

7) Hayashi T., Kitaoka T., Uto N., Hiraga G., Kondo G., Otsubo Y., Masa K., Aizawa K., Matsuda T., Kobayakawa T., Hamada A., Matsunaga H, Terada T., Saito H., J. Jpn. Soc. Hosp. Pharm., 49, 539-543 (2013).

8) Masa K., Kitaoka T., Uto N., Hiraga G., Kondo G., Otsubo Y., Hayashi T., Aizawa K., Matsuda T., Kobayakawa T., Hamada A., Matsunaga H, Terada T., Saito H., J. Jpn. Soc. Hosp. Pharm., 50, 67-70 (2014).

9) Chisaki Y., Noda S., Hira D., Morita S., Yano Y., Terada T., Biol. Pharm. Bull., 37, 1158-1161 (2014).

10) Ohishi A., Chisaki Y., Hira D., Nagasawa K., Terada T., J. Pharm. Health Care Sci., 1, 30 (2015).

11) Koyama N., Matsumura C., Morii H., Hasegawa C., Hira D., Daigo Y., Terada T., Yano Y., Am. J. Hosp. Palliat. Care, in press.

12) Ando Y., Saka H., Ando M., Sawa T., Muro K., Ueoka H., Yokoyama A., Saitoh S., Shimokata K., Hasegawa Y., Cancer Res., 60, 6921-6926 (2000) .

13) Innocenti F., Undevia S. D., Iyer L., Chen P. X., Das S., Kocherginsky M., Karrison T., Janisch L., Ramírez J., Rudin C. M., Vokes E. E., Ratain M. J., J. Clin. Oncol., 22, 13821388 (2004).

14) Terada T., Onoue M., Kobayashi M., Matsumoto S., Yanagihara K., Fukushima M., Inui K., Jpn. J. Pharm. Health Care Sci., 33, 858-862 (2007).

15) Han J. Y., Lim H. S., Shin E. S., Yoo Y. K., Park Y. H., Lee J. E., Jang I. J., Lee D. H., Lee J. S., J. Clin. Oncol., 24, 2237-2244 (2006).

16) Minami H., Sai K., Saeki M., Saito Y., Ozawa S., Suzuki K., Kaniwa N., Sawada J., Hamaguchi T., Yamamoto N., Shirao K., Yamada Y., Ohmatsu H., Kubota K., Yoshida T., Ohtsu A., Saijo N., Pharmacogenet. Genomics, 17, 497-504 (2007).
17) Gao B., Yeap S., Clements A., Balakrishnar B., Wong M., Gurney H., J. Clin. Oncol., 30, 4017-4025 (2012).

18) Picard S., Titier K., Etienne G., Teilhet E., Ducint D., Bernard M. A., Lassalle R., Marit G., Reiffers J., Begaud B., Moore N., Molimard M., Mahon F. X., Blood, 109, 3496-3499 (2007).

19) Larson R. A., Druker B. J., Guilhot F., O’Brien S. G., Riviere G. J., Krahnke T., Gathmann I., Wang Y., IRIS (International Randomized Interferon vs. STI571) Study Group, Blood, 111, 4022-4028 (2008).

20) Shinsako K., Mizuno T., Terada T., Watanabe J., Kamba T., Nakamura E., Ogawa O., Inui K., Int. J. Clin. Oncol., 15, 512514 (2010).

21) Noda S., Shioya M., Hira D., Fujiyama Y., Morita S., Terada T., Cancer Chemother. Pharmacol., 72, 269-272 (2013).

22) Mizuno T., Terada T., Kamba T., Fukudo M., Katsura T., Nakamura E., Ogawa O., Inui K., Ann. Oncol., 21, 1382-1383 (2010).

23) Mizuno T., Fukudo M., Terada T., Kamba T., Nakamura E., Ogawa O., Inui K., Katsura T., Drug Metab. Pharmacokinet., 27, 631-639 (2012).

24) Noda S., Kageyama S., Tsuru T., Kubota S., Yoshida T., Okamoto K., Okada Y., Morita S., Terada T., Case Rep. Oncol., 5, 627-632 (2012).

25) Mizuno T., Fukudo M., Fukuda T., Terada T., Dong M., Kamba T., Yamasaki T., Ogawa O., Katsura T., Inui K., Vinks A. A., Matsubara K., Ther. Drug Monit., 36, 310-316 (2014).

26) Noda S., Otsuji T., Baba M., Yoshida T., Kageyama S., Okamoto K., Okada Y., Kawauchi A., Onishi H., Hira D., Morita S., Terada T., Clin. Genitourinary Cancer, 13, 350-358 (2015).

27) Togashi Y., Masago K., Fukudo M., Terada T., Ikemi Y., Kim Y. H., Fujita S., Irisa K., Sakamori Y., Mio T., Inui K., Mishima M., $J$. Thorac. Oncol., 5, 601-605 (2010).

28) Togashi Y., Masago K., Fukudo M., Terada T., Fujita S., Irisa K., Sakamori Y., Kim Y. H., Mio T., Inui K., Mishima M., J. Thorac. Oncol., 5, 950-955 (2010). 
29) Fukudo M., Ikemi Y., Togashi Y., Masago K., Kim Y. H., Mio T., Terada T., Teramukai S., Mishima M., Inui K., Katsura T., Clin. Pharmacokinet., 52, 593-609 (2013).

30) Terada T., Noda S., Inui K., Pharmacol. Ther., 152, 125-134 (2015).

31) Noguchi K., Katayama K., Sugimoto Y., Pharmgenomics. Pers. Med., 7, 53-64 (2014).

32) Giacomini K. M., Balimane P. V., Cho S. K., Eadon M., Edeki T., Hillgren K. M., Huang S. M., Sugiyama Y., Weitz D., Wen Y., Xia C. Q., Yee S. W., Zimdahl H., Niemi M., International Transporter Consortium, Clin. Pharmacol. Ther., 94, 23-26 (2013).

33) Mendel D. B., Laird A. D., Xin X., Louie S. G., Christensen J. G., Li G., Schreck R. E., Abrams T. J., Ngai T. J., Lee L. B., Murray L. J., Carver J., Chan E., Moss K. G., Haznedar J. O., Sukbuntherng J., Blake R. A., Sun L., Tang C., Miller T., Shirazian S., McMahon G., Cherrington J. M., Clin. Cancer Res., 9, 327-337 (2003).

34) Faivre S., Delbaldo C., Vera K., Robert C., Lozahic S., Lassau N., Bello C., Deprimo S., Brega N., Massimini G., Armand J. P., Scigalla P., Raymond E., J. Clin. Oncol., 24, 25-35 (2006).

35) Noda S., Hira D., Kageyama S., Jo F., Wada A., Yoshida T., Kawauchi A., Morita S. Y., Terada T., Clin. Genitourin. Cancer, 14, e453-e456 (2016).

36) Suttle A. B., Ball H. A., Molimard M., Hutson T. E., Carpenter C., Rajagopalan D., Lin Y., Swann S., Amado R., Pandite L., Br. J. Cancer, 111, 1909-1916 (2014) .

37) Onoue M., Kato T., Terada T., Okuda M., Saito H., Fujimoto K., Doi R., Imamura M., Inui K., Jpn. J. Pharm. Health Care Sci., 29, 391-396 (2003).
38) Onoue M., Akazawa M., Terada T., Wakasugi H., Ishizu M., Inui K., Jpn. J. Pharm. Health Care Sci., 32, 424-428 (2006).

39) Kimura M., Kobayashi M., Hashida T., Terada T., Katsura T., Inui K., J. Jpn. Soc. Hosp. Pharm., 44, 1507-1510 (2008).

40) Kodama Y., Terada T., Takahashi K., Yano I., Inui K., Jpn. J. Pharm. Health Care Sci., 35, 609-614 (2009).

41) Okamura M., Takahashi K., Maruyama S., Kodawara T., Ikemi Y., Iwai C., Fukatsu S., Kobayashi M., Terada T., Yanagihara K., Inui K., J. Jpn. Soc. Hosp. Pharm., 45, 13521356 (2009).

42) Iwai C., Kobayashi M., Terada T., Yano I., Matsumoto S., Yanagihara K., Fukushima M., Inui K., Jpn. J. Pharm. Health Care Sci., 35, 866-874 (2009).

43) Sudou M., Morii H., Sakanaka M., Noda S., Wakasugi Y., Hukutake N., Kawai Y., Mekata E., Terada T., Jpn. J. Pharm. Health Care Sci., 39, 77-84 (2013).

44) Wakasugi Y., Morii H., Sudo M., Sakanaka M., Noda S., Yabuta N., Mikami T., Sonoda A., Kawai Y., Mekata E., Terada T., Jpn. J. Pharm. Health Care Sci., 41, 173-178 (2015).

45) Nakajima K., Mano Y., Ohuchi K., Sato D., Iwata K., Higuchi A., Ebara K., Kato Y., Hirosawa I., Tajima M., Tsuchiya F., Yamada H., Kotaki H., Asahi M., Jpn. J. Pharm. Health Care Sci., 38, 599-608 (2012).

46) Iihara H., Ishihara M., Matsuura K., Kurahashi S., Takahashi T., Kawaguchi Y., Yoshida K., Itoh Y., J. Eval. Clin. Pract., 18, 753760 (2012).

47) Mae Y., Yokokawa T., Kawakami K., Yagi N., Suenaga M., Shinozaki E., Matsusaka S., Mizunuma N., Hama T., Jpn. J. Pharm. Health Care Sci., 37, 611-615 (2011). 